Additional Perspectives articles for Influenza: The Cutting Edge book collection are available at http://perspectivesinmedicine.cshlp.org/cgi/collection/influenza_the_cutting_edge.

\title{
H7N9 Influenza Virus in China
}

\author{
Chengjun Li and Hualan Chen \\ State Key Laboratory of Veterinary Biotechnology, Harbin Veterinary Research Institute, Chinese Academy \\ of Agricultural Sciences, Harbin 150069, China \\ Correspondence: chenhualan@caas.cn
}

In early 2013, human infections caused by a novel H7N9 avian influenza virus (AIV) were first reported in China; these infections caused severe disease and death. The virus was initially low pathogenic to poultry, enabling it to spread widely in different provinces, especially in live poultry markets. Importantly, the H7N9 low pathogenic AIVs (LPAIVs) evolved into highly pathogenic AIVs (HPAIVs) in the beginning of 2017, causing a greater threat to human health and devastating losses to the poultry industry. Fortunately, nationwide vaccination of chickens with an $\mathrm{H} 5 / \mathrm{H} 7$ bivalent inactivated avian influenza vaccine since September 2017 has successfully controlled H7N9 avian influenza infections in poultry and, importantly, has also prevented human infections. In this review, we summarize the biological properties of the H7N9 viruses, specifically their genetic evolution, adaptation, pathogenesis, receptor binding, transmission, drug resistance, and antigenic variation, as well as the prevention and control measures. The information obtained from investigating and managing the H7N9 viruses could improve our ability to understand other novel AIVs and formulate effective measures to control their threat to humans and animals.

$D^{2}$ uring their circulation in poultry and the environment, avian influenza viruses (AIVs) sporadically infect humans. A recent threat to humans was posed by the novel H7N9 viruses. In March 2013, three cases of human infection with a previously undescribed H7N9 virus were reported in China. Two cases were reported from Shanghai municipality and one case was from Anhui Province. All three patients died from their infection (Gao et al. 2013).

Since the emergence of human H7N9 infections, five epidemic waves of human infection have occurred (Iuliano et al. 2017; Su et al. 2017). The first wave resulted in 135 human cases within 6 mo in 2013. In the four following waves, the H7N9 viruses caused 320, 226, 117, and 766 human cases, respectively. After October 2017, only four human cases were reported (Fig. 1). In total, the H7N9 virus has resulted in 1568 infection cases in humans, of which 615 cases were fatal.

The H7N9 viruses that caused the human infections during the first four waves were of low pathogenicity to poultry (Zhang et al. 2013a; Pantin-Jackwood et al. 2014). Because the viruses did not cause any symptoms in infected poultry, it was difficult to identify virusinfected poultry. This feature allowed the virus to silently spread among poultry, which was compounded by the frequent movement of

Editors: Gabriele Neumann and Yoshihiro Kawaoka

Additional Perspectives on Influenza: The Cutting Edge available at www.perspectivesinmedicine.org

Copyright (C) 2021 Cold Spring Harbor Laboratory Press; all rights reserved; doi: 10.1101/cshperspect.a038349

Cite this article as Cold Spring Harb Perspect Med 2021;11:a038349 


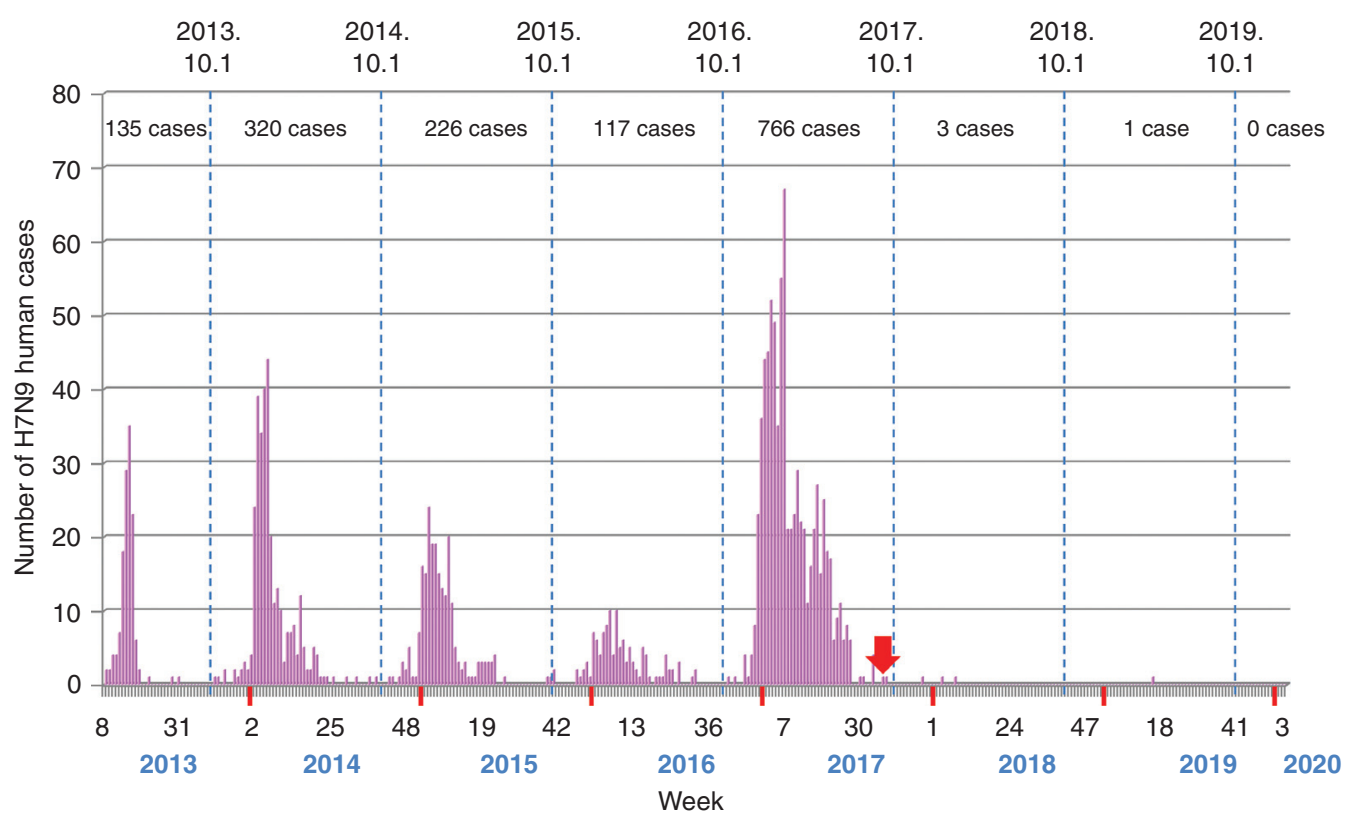

Figure 1. Human infection with $\mathrm{H} 7 \mathrm{~N} 9$ viruses. The red arrow indicates when administration of the $\mathrm{H} 5 / \mathrm{H} 7$ bivalent vaccine to poultry was initiated in China.

poultry to different regions, and by the viruses' continuing evolution in nature. After a few years of evolution, the H7N9 low pathogenic AIVs (LPAIVs) acquired multiple basic amino acids in their hemagglutinin (HA) cleavage site and evolved into highly pathogenic AIVs (HPAIVs) in early 2017 (Shi et al. 2017; Qi et al. 2018). Subsequently, H7N9 LPAIVs and HPAIVs cocirculated in the poultry of affected area. As a result, the fifth wave of human infections was caused by both low pathogenic and highly pathogenic viruses (Tang and Wang 2017).

The prevalence of H7N9 viruses caused more human infections and deaths than the H5N1 viruses within a relatively short period. The fifth wave caused the largest number of human infections, thus raising global concerns that the H7N9 virus could lead to a new influenza pandemic. The deployment of a national vaccination strategy in poultry since September 2017 in China has effectively controlled H7N9 infections in poultry and humans. Here, we summarize the biological features of the novel H7N9 virus since its emergence in 2013 and the measures employed for its effective control.

\section{EMERGENCE AND GENETIC EVOLUTION}

Live poultry markets have played pivotal roles in the genesis of novel AIVs (Zhang et al. 2013a; Han et al. 2014; Deng et al. 2015; Cui et al. 2016; Liang et al. 2016; Guan et al. 2019). There are large numbers of live poultry markets in China. Different bird species are co-housed in the live poultry markets, thus creating an environment for interspecies transmission and reassortment among different AIVs. The H7N9 AIVs that emerged in 2013 were mainly isolated from samples collected in the live poultry markets (Gao et al. 2013; Shi et al. 2013a; Zhang et al. 2013a; Han et al. 2014) and were very rarely found on poultry farms (Zhang et al. 2013a), indicating that farms may not have been a source of the H7N9 viruses. H7N9 AIVs were primarily isolated from chickens, but were also detected in ducks and pigeons, albeit in relatively low incidence (Zhang et al. 2013a). In addition, the H7N9 virus was also occasionally detected in wild birds, such as sparrows and magpie-robins (Zhao et al. 2014; Yao et al. 2018). 
During the H7N9 waves in humans, most of the human H7N9 cases were reported in areas that were epidemic for the H7N9 viruses ( $\mathrm{Li}$ et al. 2014b; Wang et al. 2015; Zhu et al. 2016; Zhou et al. 2017). The H7N9 human infections were traced back to the poultry H7N9 viruses, and most of the H7N9 human cases had a history of exposure to poultry, especially in the live poultry markets (Gao et al. 2013; Lee et al. 2013; Xu et al. 2013; Wang et al. 2014a). Retrospective analyses were often carried out when human infections were identified, and genetically closely related H7N9 viruses were often isolated from chickens or environmental samples, mostly from the exposed live poultry markets (Shi et al. 2013a). There were also several reports of clusters of human infection cases (Ding et al. 2014; Xiao et al. 2014; Mao et al. 2015; Yi et al. 2015; Xie et al. 2017; Guo et al. 2018; Wang et al. 2018; Zhang et al. 2019), although there remains no evidence of sustained human-to-human transmission (Hu et al. 2014; Dong et al. 2017; Liu et al. 2017; Wang et al. 2019).

The HA, neuraminidase (NA), and internal genes of the novel H7N9 virus were derived from different sources. The HA gene of the H7N9 virus is most closely related to that of duck $\mathrm{H} 7 \mathrm{~N} 3$ strains isolated in the Fujian and Zhejiang provinces in 2010-2011 (Gao et al. 2013; Kageyama et al. 2013; Lam et al. 2013; Shi et al. 2013a; Zhang et al. 2013a). The NA gene of H7N9 virus may have evolved from the NA gene of $\mathrm{H} 2 \mathrm{~N} 9, \mathrm{H} 4 \mathrm{~N}$, $\mathrm{H} 7 \mathrm{~N} 9$, or H11N9 progenitor viruses isolated from ducks or wild birds (Gao et al. 2013; Kageyama et al. 2013; Lam et al. 2013; Shi et al. 2013a). In comparison to the debate over the direct precursor of the NA gene, all six internal genes of the novel H7N9 virus are known to have originated from the widespread H9N2 AIVs (Gao et al. 2013; Lam et al. 2013, 2015; Shi et al. 2013a; Zhang et al. 2013a; Cui et al. 2014; Han et al. 2014; Pu et al. 2015).

The H7N9 virus continuously reassorts with other subtypes of AIVs, such as H9N2 (Qi et al. 2014; Shi et al. 2014; Yang et al. 2014), H5N1 (Wang et al. 2017), and H5N6 (Lam et al. 2015), leading to increased diversity of the gene constellations. For example, while investigating the source of an H7N9 human infection case in
Northern China, Shi et al. (2014) isolated a virus from chickens on the patient's farm that was a novel reassortant between $\mathrm{H} 7 \mathrm{~N} 9$ and $\mathrm{H} 9 \mathrm{~N} 2$ viruses, thus providing direct evidence that H7N9 viruses continue to reassort with viruses in poultry. Moreover, Liu et al. (2014c) reported H7N9/ H9N2 co-infection in 14 of 283 samples collected in live poultry markets, further demonstrating the active reassortment between H7N9 and $\mathrm{H} 9 \mathrm{~N} 2$ viruses.

The H7N9 viruses that emerged in 2013 possessed only one basic amino acid at the HA cleavage site (Gao et al. 2013; Kageyama et al. 2013; Shi et al. 2013a; Zhang et al. 2013a), which is the signature of low pathogenicity to poultry. The H7N9 LPAIVs evolved into HPAIVs in Guangdong province in the beginning of 2017 by acquiring a multibasic cleavage site motif in HA (Shi et al. 2017; Qi et al. 2018). The H7N9 HPAIVs then rapidly spread from Guangdong province to other provinces and posed a severe threat to the poultry industry and human health (Quan et al. 2018).

The frequent reassortment of H7N9 viruses with other subtypes of AIVs resulted in multiple viral genotypes. Cui et al. (2014) found a total of 27 genotypes among 109 H7N9 viruses between 2013 and 2014. Shi et al. (2017) collected a large number of samples from poultry and the environment between 2013 and 2017 and isolated 293 H7N9 viruses, including 286 LPAIVs and 7 HPAIVs, from which 23 genotypes were identified. They found that the HPAIVs from poultry and humans formed a single cluster in both the HA and NA gene, indicating that the H7N9 HPAIVs are derived from a single origin. In a subsequent study, Shi et al. showed that the H7N9 HPAIVs evolved rapidly after their emergence. Through reassorting with other subtypes of AIVs within a few months, nine genotypes of H7 HPAIV were detected, including two genotypes, G8 and G9, that emerged by reassortment between H7N9 HPAIVs and unknown duck viruses (Shi et al. 2018).

After October 2017, only four human infection cases have been reported, with the most recent case being reported in March of 2019 (Yu et al. 2019). Compared to the earlier H7N9 HPAIVs, the HA gene of the H7N9 
HPAIV from the latest human case showed a relatively long genetic distance, and the other seven gene segments also exhibited obvious genetic diversity, indicating that the H7N9 HPAIVs have evolved considerably since their emergence (Yu et al. 2019).

\section{ADAPTATION}

Like any other AIV, H7N9 AIV acquires adaptive mutations during replication in mammalian hosts. Most of the natural H7N9 isolates possess a Q226L (H3 numbering is used throughout) mutation in the HA receptor-binding site (Gao et al. 2013; Shi et al. 2017), which is a typical mammalian-adaptive marker that confers greater binding affinity to the human-type $\alpha 2,6$ sialic acid receptors (Xiong et al. 2013). The T160A mutation, acquired during serial passages of H7N9 AIV in human airway epithelial cells, is also located close to the receptor-binding site (Gao et al. 2013), which may increase the binding affinity for $\alpha 2,6$ sialic acid receptors, as observed for H5N1 viruses (Gao et al. 2009; Wang et al. 2010). In addition, Yu et al. found that the highly pathogenic H7N9 viruses isolated from a patient in 2019 possessed 135A (loss of glycosylation site) in $\mathrm{HA}$, whereas viruses isolated from the environment close to the patient had $135 \mathrm{~T}$ in $\mathrm{HA}$, indicating that the avian virus may have acquired this adaptive mutation in humans (Yu et al. 2019).

The PB2 E627K mutation is known to play a pivotal role in the mammalian adaptation of AIVs (Subbarao et al. 1993; Hatta et al. 2001; Herfst et al. 2012; Zhang et al. 2013a; Linster et al. 2014; Moket al. 2014; Shi et al. 2017). Nearly $80 \%$ of H7N9 human viruses possess the PB2 E627K mutation (Shi et al. 2017). Some H7N9 human isolates also acquired the PB2 D701N mutation (Yamayoshi et al. 2015; Shi et al. 2017; Pu et al. 2018), whose role in the mammalian adaptation of AIVs has also been well established (Gabriel et al. 2005; Li et al. 2005; Gao et al. 2009; Steel et al. 2009). Xiao et al. (2016) reported that the number of H7N9 human isolates bearing PB2 588V has increased significantly since 2013 and demonstrated that this mutation may facilitate virus adaptation in mammalian hosts.
Moreover, the T271A and Q591K mutations in PB2 have also occasionally been identified in highly pathogenic H7N9 viruses (Yang et al. 2017). Mutations in other components of the viral RNP complex, including PB1 I368V and PA K356R, which were established in the H7N9 avian viruses (He et al. 2018), as well as V100A, A404S, and S409N in PA, and V33I and I109V in NP, which were rarely observed in the highly pathogenic H7N9 human viruses (Chen et al. 2016; Yang et al. 2017), could also potentially contribute to the adaptation of H7N9 viruses in humans. Of note, mammalian-adaptive mutations were also acquired during virus replication in other mammals, such as PB2 T271A, E627K, and D701N in pigs (Liu et al. 2014b).

Because of the pivotal role of the PB2 E627K mutation in the adaptation of H7N9 AIV in humans, Liang et al. attempted to discover why the H7N9 AIV easily acquired this mutation. They generated a series of reassortants between an H7N9 AIV and an early H9N2 AIV and tested them in mice. They found that when the PA gene of the H7N9 virus was replaced with that of the H9N2 virus, the H7N9 virus lost the ability to acquire the PB2 E627K mutation during replication in mice. Further studies showed that the low polymerase activity of the H7N9 virus, conferred by the viral PA protein, is the intrinsic driving force behind the emergence of the PB2 E627K mutation during virus replication in mice. Of significance, the polymerase activity and growth of H7N9 AIV in human cells are highly compromised by knockdown or knockout of ANP32A protein. Furthermore, the impaired viral polymerase activity of H7N9 AIV due to ANP32A depletion in Anp32a $a^{-1-}$ mice abolishes the acquisition of the PB2 E627K mutation. This work thus revealed an enigma in the emergence of the critical PB2 E627K mutation, showing that both the viral PA and mammalian ANP32A are crucial for the acquisition of the PB2 E627K mutation during adaptation of H7N9 AIVs to humans (Liang et al. 2019).

\section{PATHOGENESIS}

The H7N9 viruses were initially low pathogenic to poultry. They replicate efficiently among 
chickens, but caused only asymptomatic infection (Zhang et al. 2013a; Pantin-Jackwood et al. 2014). By contrast, the H7N9 LPAIVs replicate less efficiently in ducks (Zhang et al. 2013a); however, they replicate well in different mammalian hosts, such as mice, ferrets, guinea pigs, pigs, and nonhuman primates (Belser et al. 2013; Watanabe et al. 2013; Zhang et al. 2013a; de Wit et al. 2014; Gabbard et al. 2014; Xu et al. 2014). The avian H7N9 LPAIV isolates were nonpathogenic in mice, whereas the human isolates could cause lethal infections in these rodents (Belser et al. 2013; Watanabe et al. 2013; Zhang et al. 2013a). The virulence of H7N9 LPAIVs in mammals was dramatically enhanced after they acquired the mammalian-adaptive mutations, such as PB2 E627K and D701N (Zhang et al. 2013a; Mok et al. 2014; Yamayoshi et al. 2015).

The H7N9 HPAIVs emerged in Guangdong province in early 2017, spread quickly from Southern to Northern China, and caused a number of outbreaks in poultry, resulting in the death or destruction of millions of infected or exposed birds. The H7N9 HPAIVs were 100\% lethal in chickens (Shi et al. 2017) and also caused a high mortality rate of $\sim 50 \%$ in infected patients (Ke et al. 2017; Zhou et al. 2017). Shi et al. demonstrated that an index strain of H7N9 HPAIV, A/ chicken/Guangdong/SD008/2017 (CK/SD008), was nonlethal in mice, but readily acquired the PB2 E627K or D701N mutation upon replication in ferrets. Two mutant CK/SD008 viruses displayed more than 500,000- or 12,000-fold decreases in the $50 \%$ mouse lethal dose, respectively, compared with the wild-type virus, and also caused lethal infections in ferrets (Shi et al. 2017). In a follow-up study, Shi et al. showed that during the rapid evolution of the H7N9 HPAIVs, five different motifs were detected in the HA cleavage site. The pathogenicity of these H7N9 HPAIVs was different in mice, with some of them $100 \%$ lethal in infected mice. The highly pathogenic viruses also showed distinct replication and pathogenicity in ducks. Among them, A/duck/Fujian/SD208/2017 (H7N9, G8 genotype) and A/duck/Fujian/SE0195/2018 (H7N2, G9 genotype), generated by reassortment between H7N9 HPAIVs and unknown duck viruses, caused lethal infections in ducks (Shi et al.
2018). In a similar study, Imai et al. found that an H7N9 HPAIV strain, A/Guangdong/17SF003/ 2016 (GD/SF003), was lethal and more virulent in mice than an H7N9 LPAIV. Moreover, GD/SF003 caused lethal infections in ferrets and replicated efficiently in nonhuman primates (Imai et al. 2017). Qi et al. (2018) also reported that the H7N9 HPAIVs displayed high pathogenicity in chickens, with the human viral strains also lethal to mice. Sun et al. (2018) found that the H7N9 HPAIVs exhibited enhanced lethality in mice and caused more severe infections in ferrets compared to an H7N9 LPAIV.

The pathogenicity of H7N9 viruses is a multigenic trait that is affected by different residues of different viral proteins. In addition to the critical role of the multibasic amino acid insertion at the HA cleavage site in the virulence of H7N9 HPAIVs, residue $64 \mathrm{~K}$ in HA2 has been shown to contribute to virus stability and replication in mice (Sun et al. 2019). Almost all of the H7N9 viruses isolated from humans have an amino acid change, Q591K, E627K, or D701N, in their PB2 protein (Yamayoshi et al. 2015). Numerous studies have demonstrated the significance of PB2 E627K in the replication and pathogenicity of H7N9 viruses in mammalian hosts (Mok et al. 2014; Zhang et al. 2014; Yamayoshi et al. 2015; Shi et al. 2017). Q591K or D701N can partially compensate for the absence of PB2 E627K in terms of the effect on the polymerase activity and virulence in mammalian cells (Mok et al. 2014; Yamayoshi et al. 2015). The rarely combined PB2 E627K/D701N mutations acquired during transmission of the H7N9 virus among ferrets via direct contact increased the polymerase activity and replication in mammalian cells and enhanced virulence in mice compared with the single E627K or D701N mutation (Zhu et al 2015). In addition, other mutations in the viral polymerases-PB2 K526R, A588V, or a combination of PB2 482R, 588V, and PA 497R-also contribute to the pathogenicity of H7N9 virus in humans or other mammals (Song et al. 2014; Xiao et al. 2016; Yamayoshi et al. 2018). A recent study by Ma et al. (2020) identified two residues, $286 \mathrm{~A}$ and $437 \mathrm{~T}$, in the NP protein as prerequisites for the virulence of H7N9 virus in mammals. The H7N9 viruses also harbored other 
known pathogenicity signatures, such as N30D and $\mathrm{T} 215 \mathrm{~A}$ in $\mathrm{M} 1$ and P42S in NS1, which have been shown to increase the pathogenicity of H5N1 viruses (Jiao et al. 2008; Fan et al. 2009). Moreover, Neumann et al. (2014) identified a number of amino acid changes that may have been critical for the genesis of H7N9 influenza viruses, whose roles in the pathogenicity of H7N9 viruses remain to be investigated.

H7N9 virus replicated efficiently in human lung epithelial and endothelial cells and in type II pneumocytes (Zhou et al. 2013; Zeng et al. 2015). Histochemical analysis with formalinfixed human respiratory tract tissues showed that H7N9 viruses attached moderately or abundantly to both the upper and lower respiratory tracts, which is not typical for AIVs (van Riel et al. 2013). Siegers et al. (2014) further found that the tropism of H7N9 viruses within the upper and lower respiratory tract of mammalian hosts was more widespread than that of an H5N1 HPAIV in humans, ferrets, macaques, pigs, and guinea pigs. The wide tissue tropism of H7N9 viruses may be an underlying factor correlated to the efficient replication and pathogenesis of H7N9 virus in humans.

H7N9 virus infection caused hypercytokinemia in patients (van Riel et al. 2013; Zhou et al. 2013; Wang et al. 2014b; Guo et al. 2015). Guo et al. (2015) showed that the profile of eight cytokines and chemokines could predict a fatal outcome. Similarly, Wang et al. (2014b) found that high levels of IL-6, IL-8, and MIP-1 $\beta$ in the plasma of patients were predictive of fatal infections. H7N9 virus also replicated efficiently in explanted human lung tissue (Knepper et al. 2013) and induced high levels of pro-inflammatory cytokines, such as MCP-1 and TNF- $\alpha$ in macrophages (Zhao et al. 2016). As a main virulence factor, H7N9 PB1-F2 activates the NLRP3-dependent inflammasome to induce pulmonary inflammatory infiltration, recruit cytokines, and enhance the virulence of the virus (Pinar et al. 2017).

\section{RECEPTOR BINDING}

The receptor-binding specificity of viral HA is considered to be one of the barriers for the transmission of AIV in humans. A number of studies have determined the receptor-binding specificity of H7N9 viruses. Depending on the viruses and approaches used, the receptor-binding specificity of $\mathrm{H} 7 \mathrm{~N} 9$ viruses varied among the different studies. However, these studies all showed that the H7N9 viruses displayed dual receptor-binding specificity, meaning they could bind to both human-type $\alpha 2,6$ sialic acid receptors and avian-type $\alpha 2,3$ sialic acid receptors (Table 1).

Acquiring binding affinity for $\alpha 2,6$ sialic acid receptors is a prerequisite for the efficient transmission of influenza viruses in humans (Vines et al. 1998; Matrosovich et al. 2000; Glaser et al. 2005; Herfst et al. 2012; Imai et al. 2012; Zhang et al. 2013b). Of the three earliest human H7N9 viruses, A/Shanghai/1/2013 possesses 226Q in its HA, compared with A/Shanghai/2/ 2013 and A/Anhui/1/2013, which possess 226L in their HA. The ability of A/Shanghai/1/2013 to bind to human-type receptors may be associated with the A138S substitution (Zhou et al. 2013). An L226Q HA mutant of the A/Anhui/1/2013 virus retained its dual receptor-binding property, indicating that other amino acid substitutions contribute to the ability to bind to human-type receptors (Shi et al. 2013b); further studies showed that both $226 \mathrm{~L}$ and $186 \mathrm{~V}$ of HA confer this ability (Dortmans et al. 2013; Xiong et al. 2013). Of note, in comparison to most of the H7N9 LPAIVs that contain 226L, the majority of the H7N9 HPAIVs possess 226Q (Yang et al. 2017). However, the H7N9 HPAIVs maintained the dual receptor-binding affinity ( $\mathrm{He}$ et al. 2018), indicating the G186V mutation alone is capable of increasing the human-type receptorbinding affinity. In addition, a T160A mutation in HA was acquired by the H7N9 viruses (Gao et al. 2013; Huang et al. 2017), leading to the loss of an N-glycosylation site. This mutation has also been shown to increase the human-type receptor-binding preference among the $\mathrm{H} 5 \mathrm{~N} 1 \mathrm{vi}$ ruses (Gao et al. 2009; Wang et al. 2010).

Several studies have examined the potential of H7N9 viruses to acquire enhanced humantype receptor-binding specificity. A combination of G228S in HA1 and K58I substitutions in HA2 has been shown to increase the binding 
H7N9 Influenza Virus in China

Table 1. Receptor-binding properties of H7N9 viruses in China

\begin{tabular}{|c|c|c|c|}
\hline Viruses & Methods & Receptor-binding properties & Reference \\
\hline $\begin{array}{l}\text { A/Anhui/1/2013; A/Shanghai/1/ } \\
\text { 2013; A/Shanghai/2/2013; A/ } \\
\text { chicken/Shanghai/S1053/2013; } \\
\text { A/pigeon/Shanghai/S1069/ } \\
\text { 2013; A/chicken/Shanghai/ } \\
\text { S1410/2013; A/pigeon/ } \\
\text { Shanghai/S1421/2013 }\end{array}$ & $\begin{array}{l}\text { Solid-phase binding } \\
\text { assay }\end{array}$ & $\begin{array}{l}\text { All viruses bound to human-type } \\
\alpha 2,6 \text { sialic acid receptors, } \\
\text { although they also bound to } \\
\text { avian-type } \alpha 2,3 \text { sialic acid } \\
\text { receptors with low to high } \\
\text { affinity. }\end{array}$ & $\begin{array}{l}\text { Zhang et al. } \\
\text { 2013a }\end{array}$ \\
\hline $\begin{array}{l}\text { A/Anhui/1/2013; A/Shanghai/1/ } \\
2013\end{array}$ & $\begin{array}{l}\text { Solid-phase binding } \\
\text { assay; flow } \\
\text { cytometry-based } \\
\text { binding assay }\end{array}$ & $\begin{array}{l}\text { Bound strongly to } \alpha 2,3 \text {-linked } \\
\text { sialic acids, and also displayed } \\
\text { low levels of binding to } \alpha 2,6- \\
\text { linked sialic acids; A/Anhui/1/ } \\
2013 \text { possessed higher binding } \\
\text { affinity to } \alpha 2,6 \text {-linked sialic } \\
\text { acids than did A/Shanghai/1/ } \\
2013 \text {. }\end{array}$ & $\begin{array}{l}\text { Ramos et al. } \\
2013\end{array}$ \\
\hline A/Anhui/1/2013 & Biolayer interferometry & $\begin{array}{l}\text { A/Anhui/1/2013 virus showed a } \\
\text { lower binding avidity to avian- } \\
\text { type receptors and higher } \\
\text { binding avidity to human-type } \\
\text { receptors than an avian H7N3 } \\
\text { virus, while maintaining avian- } \\
\text { type receptor-binding } \\
\text { preference. }\end{array}$ & $\begin{array}{l}\text { Xiong et al. } \\
2013\end{array}$ \\
\hline $\begin{array}{l}\text { A/Anhui/1/2013; A/Shanghai/1/ } \\
\text { 2013; A/Shanghai/2/2013 }\end{array}$ & $\begin{array}{l}\text { Solid-phase binding } \\
\text { assay }\end{array}$ & $\begin{array}{l}\text { All three viruses bound to both } \\
\text { avian-type }(\alpha 2,3) \text { and human- } \\
\text { type }(\alpha 2,6) \text { receptors. }\end{array}$ & $\begin{array}{l}\text { Zhou et al. } \\
2013\end{array}$ \\
\hline $\begin{array}{l}\text { A/Anhui/1/2013; A/Shanghai/1/ } \\
2013\end{array}$ & Glycan array analysis & $\begin{array}{l}\text { A/Shanghai/1/2013 bound to a } \\
\text { broader array of } \alpha 2,3 \text { sialic } \\
\text { acids than } \alpha 2,6 \text { sialic acids, } \\
\text { whereas } \mathrm{A} / \text { Anhui/ } 1 / 2013 \\
\text { exhibited binding to both } \alpha 2,3 \\
\text { and } \alpha 2,6 \text { sialic acids. }\end{array}$ & $\begin{array}{l}\text { Belser et al. } \\
2013\end{array}$ \\
\hline $\begin{array}{l}\text { Reassortant viruses possessing the } \\
\text { A/Anhui/1/2013, A/Shanghai/ } \\
\text { 1/2013, or A/Hangzhou/1/ } \\
\text { 2013 HA genes in combination } \\
\text { with the A/Anhui/1/2013 NA } \\
\text { gene, and the remaining genes } \\
\text { from A/Puerto Rico/8/34 } \\
\text { (H1N1) }\end{array}$ & Glycan array analysis & $\begin{array}{l}\text { The two viruses possessing A/ } \\
\text { Anhui/1/2013 and A/ } \\
\text { Hangzhou/1/2013 HAs bound } \\
\text { strongly to } \alpha 2,6 \text {-linked } \\
\text { sialosides, whereas the virus } \\
\text { containing A/Shanghai/1/ } \\
2013 \mathrm{HA} \text { bound equally well to } \\
\text { both } \alpha 2,6-\text { and } \alpha 2,3 \text {-linked } \\
\text { sialosides. }\end{array}$ & $\begin{array}{l}\text { Watanabe } \\
\text { et al. } 2013\end{array}$ \\
\hline $\begin{array}{l}\text { A/Anhui/1/2013; A/Guangdong/ } \\
\text { 17SF003/2016 (highly } \\
\text { pathogenic); A/Guangdong/ } \\
\text { 17SF006/2017 (highly } \\
\text { pathogenic) }\end{array}$ & $\begin{array}{l}\text { Solid-phase binding } \\
\text { assay }\end{array}$ & $\begin{array}{l}\text { A/Anhui/1/2013 virus bound to } \\
\text { sialic acid } \alpha 2,3 \text { and } \alpha 2,6 \\
\text { receptors, and the two H7N9 } \\
\text { HPAIVs showed typical dual } \\
\text { receptor preference, with } \\
\text { increased affinity to } \alpha 2,3 \text { sialic } \\
\text { acid receptors compared with } \\
\text { A/Anhui/1/2013 virus. }\end{array}$ & $\begin{array}{l}\text { Zhu et al. } \\
2017\end{array}$ \\
\hline
\end{tabular}


C. Li and H. Chen

Table 1. Continued

\begin{tabular}{lclc}
\hline Viruses & \multicolumn{1}{c}{ Methods } & Receptor-binding properties & Reference \\
\hline $\begin{array}{l}\text { Six H7N9 LPAIVs and six H7N9 } \\
\text { HPAIVs }\end{array}$ & $\begin{array}{c}\text { Solid-phase glycan- } \\
\text { coated ELISA }\end{array}$ & $\begin{array}{c}\text { All six low pathogenic viruses and } \\
\text { five of the six highly }\end{array}$ & He et al. \\
& & pathogenic viruses bound well & 2018 \\
& & to both human-type and \\
& avian-type receptors, whereas \\
& one of the six highly \\
& pathogenic viruses bound only \\
& to avian-type receptors. \\
\hline
\end{tabular}

(HA) Hemagglutinin, (NA) neuraminidase, (HPAIVs) highly pathogenic avian influenza viruses, (ELISA) enzyme-linked immunoabsorbent assay.

affinity for $\alpha 2,6$ sialic acid receptors (Schrauwen et al. 2016). Structural analysis demonstrated that an additional G228S mutation in the HA of the A/Anhui/1/2013 virus would allow extensive binding to human-type receptors (Tharakaraman et al. 2013). de Vries and colleagues reported that in the background of A/Shanghai/2/2013 virus, the introduction of two different 3-amino acid mutations (i.e., V186G/KK193T-G228S or V186N-N224K-G228S) can switch the receptor-binding specificity from avian- to human-type (de Vries et al. 2017). The combination of V186K-K193T-G228S mutations in the HA of two fifth-wave H7N9 viruses was also shown to switch the receptor-binding specificity to human-type (Yang et al. 2018a). Of these three mutations, the K193T mutation has also been shown to increase the human-type receptor-binding specificity of $\mathrm{H} 10 \mathrm{~N} 8$ virus (Tzarum et al. 2017).

The optimal balance between the receptorbinding activity of $\mathrm{HA}$ and the receptor-destroying activity of NA is critical for influenza virus to infect its host. The NA of H7N9 virus possessed $401 \mathrm{~A}$ instead of $401 \mathrm{~T}$ in the second sialic acidbinding site, which led to reduced sialidase activity. The acquisition of this T401A mutation, which preceded the emergence of the H7N9 virus, is proposed to have driven the selection of HA mutations that confer dual receptor-binding properties (Dai et al. 2017). A secondary sialic acid-binding site in the NA protein of the H7N9 viruses was also proposed to contribute to the virus binding to sialic acid receptors (Benton et al. 2017). In addition, the unusual kinetic properties of the NA sialidase site, characterized by higher binding but lower cleavage of humantype receptors, promoted the binding via this site to sialic acid receptors, and particularly to human-type receptors (Benton et al. 2017).

\section{TRANSMISSION}

There are two modes of transmissibility of influenza virus: direct contract transmission and respiratory droplet transmission ( $\mathrm{Li}$ and Chen 2014). It is believed that sustained respiratory droplet transmissibility is an essential property of pandemic and epidemic influenza viruses. The H7N9 viruses spread widely in poultry in China, which is attributed to its efficient transmissibility among poultry (Zhang et al. 2013a). Of greater concern is the potential of $\mathrm{H} 7 \mathrm{~N} 9$ virus to acquire efficient transmissibility among humans, thereby evolving into a pandemic virus.

Guinea pigs and ferrets are two well-established animal models for the evaluation of transmissibility of influenza viruses (Gao et al. 2009; Steel et al. 2009; Herfst et al. 2012; Imai et al. 2012; Zhang et al. 2013b). The H7N9 viruses, especially the human isolates, transmitted efficiently among guinea pigs or ferrets via direct contact (Belser et al. 2013; Zhu et al. 2013; Gabbard et al. 2014; Luk et al. 2015; Sun et al. 2018). Compared with natural H5N1 viruses, which have never acquired respiratory droplet transmissibility, many studies have reported that both H7N9 LPAIV and HPAIV can transmit via respiratory droplets in guinea pigs and ferrets, although the efficiency of virus transmis- 
sion differs in different studies (Belser et al. 2013; Richard et al. 2013; Watanabe et al. 2013; Zhang et al. 2013a; Zhu et al. 2013; Xu et al. 2014; Kong et al. 2015; Imai et al. 2017; Shi et al. 2017; Yang et al. 2018b). For example, the respiratory droplet transmissibility of a series of $\mathrm{H} 7 \mathrm{~N} 9$ viruses was shown to vary from low to high in studies by Zhang et al. (2013a) and Kong et al. (2019). In particular, the A/Anhui/1/ 2013 virus was found to transmit to $3 / 3$ exposed ferrets or guinea pigs via respiratory droplets (Zhang et al. 2013a; Kong et al. 2019). Notably, the respiratory droplet transmissibility of H7N9 viruses could be greatly enhanced by certain mutations, such as PB2 627K, 701N, 292V, and M1 156D (Shi et al. 2017; Kong et al. 2019).

\section{DRUG RESISTANCE}

The M2 inhibitors, including amantadine and rimantadine, were the first anti-influenza drugs used for the clinical treatment of patients (Stiver 2003). An S $31 N$ mutation in the M2 protein confers resistance to amantadine (Pielak et al. 2009). Sequence analyses showed that all of the $\mathrm{H} 7 \mathrm{~N} 9$ viruses possess the $\mathrm{S} 31 \mathrm{~N}$ mutation in the M2 protein (Chen et al. 2013; Gao et al. 2013; Shi et al. 2013a; Zhou et al. 2013), indicating that they are resistant to amantadine. Consequently, the M2 inhibitors are not effective for the treatment of H7N9 virus infections.

The second class of anti-influenza drugs is the NA inhibitors, which include oseltamivir, zanamivir, peramivir, and laninamivir (Samson et al. 2013; Loregian et al. 2014). In clinical settings, NA inhibitors were used to treat H7N9 virus-infected patients. However, some of the H7N9 isolates acquired the R292K mutation as well as other mutations (i.e., E119V, I222K/R, $\mathrm{A} 246 \mathrm{~T}$ ) in the viral NA protein, which confer drug resistance during treatment of patients with oseltamivir (Hay and Hayden 2013; Zhu et al. 2013; Liu et al. 2014a; Marjuki et al. 2015; Song et al. 2015). The emergence of drug-resistant H7N9 virus usually occurred within 1-9 d after drug administration (Gao et al. 2013; Zhu et al. 2013). H7N9 virus encoding the $\mathrm{R} 292 \mathrm{~K}$ mutation in NA is most resistant to the NA inhibitors, followed by viruses encod- ing E119V, and finally those encoding the I222K/R mutation (Hai et al. 2013; Yen et al. 2013; Liu et al. 2014a; Marjuki et al. 2015). Of note, none of these mutations occurred in the avian H7N9 viruses, indicating that these mutations were acquired during the treatment of patients with the NA inhibitors (Wang et al. 2016). Moreover, these NA inhibitor-resistant mutations in H7N9 virus (i.e., NA R292K and I222T) were also observed in nonhuman primates during oseltamivir treatment (Itoh et al. 2015; Kiso et al. 2017)

The fitness of the R292K mutant H7N9 viruses varied among studies. Hai et al. showed that the NA R292K mutant H7N9 virus is comparable to wild-type virus in terms of their replication in human respiratory cells, virulence in mice, and transmissibility in guinea pigs (Hai et al. 2013). By contrast, others reported that the $\mathrm{R} 292 \mathrm{~K}$ mutation reduced the virus fitness in the ferret model (Yen et al. 2014; Marjuki et al. 2015). Notably, in the absence of NA inhibitors, the R292K mutant virus reverted back to $292 \mathrm{R}$ during growth in embryonated eggs, MDCK-SIAT1 cells, or HAE cells, suggesting that the R292K mutation may compromise the fitness of the H7N9 virus (Sleeman et al. 2013; Huang et al. 2017).

\section{ANTIGENICITY}

The viral HA gene also gained mutations that affect virus antigenicity. An A135T mutation in the HA of some H7N9 viruses, resulting in the acquisition of an $\mathrm{N}$-linked glycosylation site at residue 133 of HA, combined with the $\$ 128 \mathrm{~N}$ mutation, reduced the reactivity to antiserum raised with the prototype A/Anhui/1/2013 virus (Liu et al. 2016).

In parallel with the significant genetic change during the fifth wave, the H7N9 viruses also underwent detectable antigenic change. In comparison to the A/Shanghai/2/2013 virus, A122T, S128N, A135V, and R140K substitutions on antigenic site A of HA1 were seen in the low pathogenic A/Hong Kong/125/2017 virus (recommended by the World Health Organization $[\mathrm{WHO}]$ as a candidate human vaccine virus), and A122P, S128N, L226Q, and G270R 
substitutions on antigenic sites $\mathrm{A}, \mathrm{C}$, and D were identified in another candidate vaccine virus, highly pathogenic A/Guangdong/17SF003/ 2016 virus (Yang et al. 2018a). The role of L226Q in the antigenic change of the H7N9 viruses was demonstrated by Chang et al., whose study showed that the L226Q mutation is critical for the antigenic differences between H7N9 LPAIVs and HPAIVs (Chang et al. 2019). Notably, 90\% of highly pathogenic H7N9 virus contained 226Q, whereas $>95 \%$ of low pathogenic H7N9 viruses had 226L (Chang et al. 2019). Yu et al. (2019) further showed that in comparison to the earlier H7N9 HPAIVs, the H7N9 HPAIVs isolated in 2019 were under selection at potential antigenic sites, such as R57K, G124R, V135T/A, and S145P, indicating that the new H7N9 HPAIVs may have undergone a certain degree of antigenic variation.

\section{PREVENTION AND CONTROL}

Given that the live poultry markets are the primary source of human infections, their periodic closure was enforced by local governments during the H7N9 epidemic waves. The evidence is clear that market closures, which substantially reduced human exposure to poultry, were effective in preventing $\mathrm{H} 7 \mathrm{~N} 9$ virus infections in humans (Li et al. 2014b; Yu et al. 2014). During the closures, H7N9 viral RNA detection and isolation rates in retail markets were shown to decrease by $79 \%$ and $92 \%$, respectively, indicating that market closure and disinfection rapidly reduce the amount of viable virus in the market environment (Yuan et al. 2015).

Because of the severe threat to human and animal health posed by H7N9 viruses, prevention and control became a top priority in China. In addition to the slaughter of infected poultry, vaccination was considered as a control strategy. The National Avian Influenza Reference Laboratory of China has established several platforms for the development of avian influenza vaccines, including the reverse genetics-based inactivated vaccine (Tian et al. 2005), the recombinant Newcastle disease virus (NDV)-vectored HA vaccine (Ge et al. 2007), the recombinant duck enteritis virus (DEV)-vectored HA vaccine (Liu et al. 2011), and the DNA vaccine (Jiang et al. 2007). The inactivated vaccine and the recombinant NDV-vectored H5HA vaccine have been widely used in China to control H5 avian influenza since 2004 and 2006, respectively (Li et al. 2014a). To combat the H7N9 epidemics in China, the inactivated vaccine was developed by using reverse genetics. To limit the number of poultry immunizations, an $\mathrm{H} 5 / \mathrm{H} 7$ bivalent inactivated vaccine was formulated by using the H7N9-Re1 and H5-Re8 seed viruses containing the HA and NA genes of A/pigeon/Shanghai/ S1069/2013 (H7N9) and A/chicken/Guizhou/4/ 2013 (H5N1), respectively, and the six internal genes of the A/Puerto Rico/8/34 virus (Zeng et al. 2018). The efficacy and safety of the bivalent vaccine were fully demonstrated in the laboratory setting, as well as in field tests in three provinces of China: Guangdong, Guangxi, and Heilongjiang (Zeng et al. 2018). This massive vaccination program has been employed in chickens since September 2017 (Shi et al. 2018).

Before and after the implementation of the national vaccination program with the $\mathrm{H} 5 / \mathrm{H} 7$ bivalent inactivated vaccine, Shi et al. (2018) performed two rounds of large-scale active surveillance of AIVs. During the first round of surveillance, between February and May of 2017, 30,201 swab samples were collected from live poultry markets and poultry farms, resulting in the isolation of 250 H7N9 LPAIVs and 56 H7N9 HPAIVs; the H7N9 LPAIVs were detected in 24 provinces, and the HPAIVs were detected in four provinces. The second round of surveillance was carried out after the initiation of the poultry vaccination program. A total of 23,683 samples were collected from which only two LPAIVs and 14 HPAIVs of H7N9 subtype were isolated; H7N9 LPAIVs and HPAIVs were isolated in two and four provinces, respectively. In clear contrast, the isolation rate of $\mathrm{H} 7 \mathrm{~N} 9$ virus was $1.013 \%$ in the prevaccination period, compared with only $0.068 \%$ in the postvaccination period (Zeng et al. 2018). Therefore, vaccination dramatically limited the prevalence of H7N9 virus in poultry: The virus isolation rate dropped by $93.3 \%$. The effectiveness of the vaccination strategy in preventing and controlling H7N9 avian influenza was also demonstrated by $\mathrm{Wu}$ 
et al. (2019), whose study reported that a $92 \%$ reduction in $\mathrm{H} 7$-positive rates among poultry was associated with $\mathrm{H} 5 / \mathrm{H} 7$ bivalent vaccination in Guangdong province. More importantly, the vaccination of poultry successfully prevented the emergence of new waves of human H7N9 infection: Only four human cases were reported after September 2017 (Fig. 1). Therefore, vaccination of poultry greatly alleviated the risk of an H7N9 pandemic.

The H5/H7 bivalent vaccine continues to be used in chickens. To ensure optimal protection against AIVs, the H7N9 vaccine seed virus was updated at the end of 2018 with the new H7N9 Re- 2 vaccine strain bearing the HA (the cleavage site was modified to resemble that of the LPAIVs, and the receptor-binding site was modified to display only avian-type receptor-binding specificity) and NA genes from an H7N9 HPAIV, A/chicken/Guangxi/SD098/2017. It is important to note that the effectiveness of the vaccination strategy was determined by the vaccination coverage rate, which is high in developed regions, but relatively low in less developed regions as a result of inadequate investment of efforts and funds. The four human H7N9 cases after October 2017 occurred in such less developed regions-namely, Gansu province and the Inner Mongolia autonomous region. Moreover, the active surveillance conducted by the National Avian Influenza Reference Laboratory also detected the persistence of H7N9 viruses in some areas. As a result, the H7N9 virus could evolve further in the field. Therefore, follow-up studies should be continuously undertaken to monitor the evolution and spread of H7N9 viruses and to investigate the biological characteristics of newly discovered viruses.

\section{CONCLUDING REMARKS}

The H7N9 viruses that emerged in 2013 spread widely and evolved in China, caused severe disease and death in humans, bound human-type receptors, was capable of respiratory droplet transmission among animal models, and displayed antigenicity variation during circulation and antiviral drug resistance during treatment of patients. All of these properties indicate the
$\mathrm{H} 7 \mathrm{~N} 9$ viruses are a potential candidate to cause a new influenza pandemic. Fortunately, the control measures taken in China have proven effective. In particular, the national vaccination strategy with the $\mathrm{H} 5 / \mathrm{H} 7$ bivalent avian influenza vaccine effectively controlled outbreaks and the circulation of $\mathrm{H} 7 \mathrm{~N} 9$ viruses in poultry, significantly reducing the virus load in the environment, and clearly preventing further H7N9 virus infections in humans.

The H7N9 epidemics taught us that a LPAIV can emerge through reassortment and have a huge impact on human health. After evolving into a highly pathogenic virus, the H7N9 viruses became an even greater threat to human health and caused severe damage to the poultry industry. The emergence of H7N9 epidemics is inevitably associated with the poultry farming system in China, which comprises large numbers of small-scale or even backyard farms, the wide distribution of live poultry markets, and long-distance transportation of poultry, thus creating favorable conditions for the generation of new reassortment viruses from different sources. Given the ecosystem for the genesis of AIVs in China, comprehensive prevention and control strategies must be implemented, including biosafety measures, active surveillance, culling of infected poultry, and vaccination.

\section{ACKNOWLEDGMENTS}

We thank Susan Watson for editing the manuscript. Work in the authors' laboratory was supported by the National Natural Science Foundation of China (NSFC) (31521005, 31672582), the National Key Research and Development Program of China (2016YFD0500203, 2016YF D0500205), and the Natural Science Foundation of Heilongjiang Province (JQ2019 C005).

This article has been made freely available online courtesy of TAUNS Laboratories.

\section{REFERENCES}

Belser JA, Gustin KM, Pearce MB, Maines TR, Zeng H, Pappas C, Sun X, Carney PJ, Villanueva JM, Stevens J, et al. 2013. Pathogenesis and transmission of avian influ- 
C. Li and H. Chen

enza A (H7N9) virus in ferrets and mice. Nature 501: 556-559. doi:10.1038/nature12391

Benton DJ, Wharton SA, Martin SR, McCauley JW. 2017. Role of neuraminidase in influenza A(H7N9) virus receptor binding. J Virol 91: e02293-16. doi:10.1128/JVI .02293-16

Chang PX, Sealy JE, Sadeyen JR, Iqbal M. 2019. Amino acid residue 217 in the hemagglutinin glycoprotein is a key mediator of avian influenza H7N9 virus antigenicity. $J$ Virol 93: e01627-18.

Chen Y, Liang W, Yang S, Wu N, Gao H, Sheng J, Yao H, Wo J, Fang Q, Cui D, et al. 2013. Human infections with the emerging avian influenza A H7N9 virus from wet market poultry: clinical analysis and characterisation of viral genome. Lancet 381: 1916-1925. doi:10.1016/S0140-6736 (13)60903-4

Chen GW, Kuo SM, Yang SL, Gong YN, Hsiao MR, Liu YC, Shih SR, Tsao KC. 2016. Genomic signatures for avian H7N9 viruses adapting to humans. PLoS One 11: e0148432. doi:10.1371/journal.pone.0148432

Cui LB, Liu D, Shi WF, Pan JC, Qi X, Li XB, Guo XL, Zhou $\mathrm{MH}, \mathrm{Li}$ W, Li J, et al. 2014. Dynamic reassortments and genetic heterogeneity of the human-infecting influenza A (H7N9) virus. Nat Commun 5: 3142. doi:10.1038/ ncomms 4142

Cui PF, Deng GH, Shi JZ, Kong HH, Liu LL, Guan YT, Suzuki Y, Chen HL. 2016. New influenza A(H7N7) viruses detected in live poultry markets in China. Virology 499: 165-169. doi:10.1016/j.virol.2016.06.015

Dai ML, McBride R, Dortmans JCFM, Peng WJ, Bakkers MJG, de Groot RJ, van Kuppeveld FJM, Paulson JC, de Vries E, de Haan CAM. 2017. Mutation of the second sialic acid-binding site, resulting in reduced neuraminidase activity, preceded the emergence of H7N9 influenza A virus. J Virol 91: e00049-17.

Deng GH, Shi JZ, Wang J, Kong HH, Cui PF, Zhang F, Tan D, Suzuki Y, Liu LL, Jiang YP, et al. 2015. Genetics, receptor binding, and virulence in mice of H10N8 influenza viruses isolated from ducks and chickens in live poultry markets in China. J Virol 89: 6506-6510. doi:10.1128/JVI .00017-15

de Vries RP, Peng W, Grant OC, Thompson AJ, Zhu X, Bouwman KM, de la Pena ATT, van Breemen MJ, Ambepitiya Wickramasinghe IN, de Haan CAM, et al. 2017. Three mutations switch H7N9 influenza to human-type receptor specificity. PLoS Pathog 13: e1006390. doi:10 .1371/journal.ppat.1006390

de Wit E, Rasmussen AL, Feldmann F, Bushmaker T, Martellaro C, Haddock E, Okumura A, Proll SC, Chang J, Gardner D, et al. 2014. Influenza virus A/Anhui/1/2013 (H7N9) replicates efficiently in the upper and lower respiratory tracts of cynomolgus macaques. MBio 5: e01331-14. doi:10.1128/mBio.01331-14

Ding H, Chen Y, Yu Z, Horby PW, Wang FJ, Hu JF, Yang XH, Mao HY, Qin SW, Chai CL, et al. 2014. A family cluster of three confirmed cases infected with avian influenza A (H7N9) virus in Zhejiang Province of China. BMC Infect Dis 14: 698. doi:10.1186/s12879-014-0698-6

Dong W, Yang K, Xu QL, Liu L, Chen J. 2017. Spatio-temporal pattern analysis for evaluation of the spread of human infections with avian influenza $\mathrm{A}(\mathrm{H} 7 \mathrm{~N} 9)$ virus in
China, 2013-2014. BMC Infect Dis 17: 704. doi:10.1186/ s12879-017-2781-2

Dortmans JCFM, Dekkers J, Wickramasinghe INA, Verheije MH, Rottier PJM, van Kuppeveld FJM, de Vries E, de Haan CAM. 2013. Adaptation of novel H7N9 influenza A virus to human receptors. Sci Rep 3: 3058. doi:10.1038/ srep03058

Fan SF, Deng GH, Song JS, Tian GB, Suo YB, Jiang YP, Guan YT, Bu ZG, Kawaoka Y, Chen HL. 2009. Two amino acid residues in the matrix protein $\mathrm{M} 1$ contribute to the virulence difference of $\mathrm{H} 5 \mathrm{~N} 1$ avian influenza viruses in mice. Virology 384: 28-32. doi:10.1016/j.virol.2008.11.044

Gabbard JD, Dlugolenski D, Van Riel D, Marshall N, Galloway SE, Howerth EW, Campbell PJ, Jones C, Johnson S, Byrd-Leotis L, et al. 2014. Novel H7N9 influenza virus shows low infectious dose, high growth rate, and efficient contact transmission in the guinea pig model. J Virol 88: 1502-1512. doi:10.1128/JVI.02959-13

Gabriel G, Dauber B, Wolff T, Planz O, Klenk HD, Stech J. 2005. The viral polymerase mediates adaptation of an avian influenza virus to a mammalian host. Proc Natl Acad Sci 102: 18590-18595. doi:10.1073/pnas .0507415102

Gao Y, Zhang Y, Shinya K, Deng G, Jiang Y, Li Z, Guan Y, Tian G, Li Y, Shi J, et al. 2009. Identification of amino acids in HA and PB2 critical for the transmission of H5N1 avian influenza viruses in a mammalian host. PLoS Pathog 5: e1000709. doi:10.1371/journal.ppat.1000709

Gao R, Cao B, Hu Y, Feng Z, Wang D, Hu W, Chen J, Jie Z, Qiu H, Xu K, et al. 2013. Human infection with a novel avian-origin influenza A (H7N9) virus. New Engl J Med 368: 1888-1897. doi:10.1056/NEJMoa1304459

Ge J, Deng G, Wen Z, Tian G, Wang Y, Shi J, Wang X, Li Y, Hu S, Jiang Y, et al. 2007. Newcastle disease virus-based live attenuated vaccine completely protects chickens and mice from lethal challenge of homologous and heterologous H5N1 avian influenza viruses. J Virol 81: 150-158. doi:10.1128/JVI.01514-06

Glaser L, Stevens J, Zamarin D, Wilson IA, García-Sastre A, Tumpey TM, Basler CF, Taubenberger JK, Palese P. 2005. A single amino acid substitution in 1918 influenza virus hemagglutinin changes receptor binding specificity. J Virol 79: 11533-11536. doi:10.1128/JVI.79.17.1153311536.2005

Guan L, Shi J, Kong X, Ma S, Zhang Y, Yin X, He X, Liu L, Suzuki Y, Li C, et al. 2019. H3N2 avian influenza viruses detected in live poultry markets in China bind to humantype receptors and transmit in guinea pigs and ferrets. Emerg Microbes Infec 8: 1280-1290. doi:10.1080/ 22221751.2019.1660590

Guo J, Huang F, Liu J, Chen Y, Wang W, Cao B, Zou Z, Liu S, Pan J, Bao C, et al. 2015. The serum profile of hypercytokinemia factors identified in H7N9-infected patients can predict fatal outcomes. Sci Rep 5: 10942. doi:10.1038/ srep 10942

Guo L, Hou M, Ning RT, Li WL, Yang ZN, Li H, Chu MM, Yu L, Liu LD. 2018. A family cluster of two fatal cases infected with influenza A (H7N9) virus in Kunming China, 2017. Infect Genet Evol 66: 152-158. doi:10.1016/j .meegid.2018.09.022

Hai R, Schmolke M, Leyva-Grado VH, Thangavel RR, Margine I, Jaffe EL, Krammer F, Solórzano A, García-Sastre A, 
Palese $P$, et al. 2013. Influenza A(H7N9) virus gains neuraminidase inhibitor resistance without loss of in vivo virulence or transmissibility. Nat Commun 4: 2854. doi:10 $.1038 /$ ncomms 3854

Han J, Wang L, Liu J, Jin M, Hao F, Zhang P, Zhang Z, Wen $\mathrm{D}, \mathrm{Wu} \mathrm{X}, \mathrm{Liu} \mathrm{G}$, et al. 2014. Cocirculation of three hemagglutinin and two neuraminidase subtypes of avian influenza viruses in Huzhou, China, April 2013: implication for the origin of the novel H7N9 virus. J Virol 88: 65066511. doi:10.1128/JVI.03319-13

Hatta M, Gao P, Halfmann P, Kawaoka Y. 2001. Molecular basis for high virulence of Hong Kong H5N1 influenza A viruses. Science 293: 1840-1842. doi:10.1126/science .1062882

Hay AJ, Hayden FG. 2013. Oseltamivir resistance during treatment of H7N9 infection. Lancet 381: 2230-2232. doi:10.1016/S0140-6736(13)61209-X

He LH, Liu D, Hu J, Sun WQ, Gao RY, Shi L, He DC, Li B, Wang XQ, Gu M, et al. 2018. A comprehensive comparison of the fifth-wave highly pathogenic and low-pathogenic H7N9 avian influenza viruses reveals potential threat posed by both types of viruses in mammals. Transbound Emerg Dis 65: 1459-1473. doi:10.1111/tbed.12954

Herfst S, Schrauwen EJA, Linster M, Chutinimitkul S, de Wit E, Munster VJ, Sorrell EM, Bestebroer TM, Burke DF Smith DJ, et al. 2012. Airborne transmission of influenza A/H5N1 virus between ferrets. Science 336: 1534-1541. doi:10.1126/science. 1213362

Hu J, Zhu Y, Zhao B, Li J, Liu L, Gu K, Zhang W, Su H, Teng Z, Tang S, et al. 2014. Limited human-to-human transmission of avian influenza A(H7N9) virus, Shanghai, China, March to April 2013. Eurosurveillance 19: 23-32.

Huang DTN, Lu CY, Chi YH, Li WL, Chang LY, Lai MJ, Chen JS, Hsu WM, Huang LM. 2017. Adaptation of influenza A (H7N9) virus in primary human airway epithelial cells. Sci Rep 7: 11300. doi:10.1038/s41598-01710749-5

Imai M, Watanabe T, Hatta M, Das SC, Ozawa M, Shinya K, Zhong GX, Hanson A, Katsura H, Watanabe S, et al. 2012. Experimental adaptation of an influenza H5 HA confers respiratory droplet transmission to a reassortant $\mathrm{H} 5 \mathrm{HA} /$ H1N1 virus in ferrets. Nature 486: 420-428. doi:10.1038/ nature 10831

Imai $\mathrm{M}$, Watanabe $\mathrm{T}$, Kiso $\mathrm{M}$, Nakajima N, Yamayoshi $\mathrm{S}$, Iwatsuki-Horimoto K, Hatta M, Yamada S, Ito M, SakaiTagawa Y, et al. 2017. A highly pathogenic avian H7N9 influenza virus isolated from a human is lethal in some ferrets infected via respiratory droplets. Cell Host Microbe 22: 615-626.e8. doi:10.1016/j.chom.2017.09.008

Itoh $\mathrm{Y}$, Shichinohe S, Nakayama M, Igarashi M, Ishii A, Ishigaki $\mathrm{H}$, Ishida $\mathrm{H}$, Kitagawa N, Sasamura T, Shiohara M, et al. 2015. Emergence of H7N9 influenza A virus resistant to neuraminidase inhibitors in nonhuman primates. Antimicrob Agents Ch 59: 4962-4973. doi:10 .1128/AAC.00793-15

Iuliano AD, Jang Y, Jones J, Davis CT, Wentworth DE, Uyeki TM, Roguski K, Thompson MG, Gubareva L, Fry AM, et al. 2017. Increase in human infections with avian influenza $\mathrm{A}(\mathrm{H} 7 \mathrm{~N} 9)$ virus during the fifth epidemic-China, October 2016-February 2017. MMWR 66: 254-255.

Jiang Y, Yu K, Zhang H, Zhang P, Li C, Tian G, Li Y, Wang X, $\mathrm{Ge} \mathrm{J,} \mathrm{Bu} \mathrm{Z,} \mathrm{et} \mathrm{al.} \mathrm{2007.} \mathrm{Enhanced} \mathrm{protective} \mathrm{efficacy} \mathrm{of} \mathrm{H5}$ subtype avian influenza DNA vaccine with codon optimized HA gene in a pCAGGS plasmid vector. Antivir Res 75: 234-241. doi:10.1016/j.antiviral.2007.03.009

Jiao PR, Tian GB, Li YB, Deng GH, Jiang YP, Liu C, Liu WL, Bu ZG, Kawaoka Y, Chen HL. 2008. A single-amino-acid substitution in the NS1 protein changes the pathogenicity of H5N1 avian influenza viruses in mice. J Virol 82: 11461154. doi:10.1128/JVI.01698-07

Kageyama T, Fujisaki S, Takashita E, Xu H, Yamada S, Uchida Y, Neumann G, Saito T, Kawaoka Y, Tashiro M. 2013. Genetic analysis of novel avian A(H7N9) influenza viruses isolated from patients in China, February to April 2013. Eurosurveillance 18: 20453.

Ke C, Mok CKP, Zhu W, Zhou H, He J, Guan W, Wu J, Song W, Wang D, Liu J, et al. 2017. Human infection with highly pathogenic avian influenza $\mathrm{A}(\mathrm{H} 7 \mathrm{~N} 9)$ virus, China. Emerg Infect Dis 23: 1332-1340. doi:10.3201/eid2308 .170600

Kiso M, Iwatsuki-Horimoto K, Yamayoshi S, Uraki R, Ito M, Nakajima N, Yamada S, Imai M, Kawakami E, Tomita Y, et al. 2017. Emergence of oseltamivir-resistant H7N9 influenza viruses in immunosuppressed cynomolgus macaques. J Infect Dis 216: 582-593. doi:10.1093/infdis/ jix296

Knepper J, Schierhorn KL, Becher A, Budt M, Tönnies M, Bauer TT, Schneider P, Neudecker J, Rückert JC, Gruber $\mathrm{AD}$, et al. 2013. The novel human influenza $\mathrm{A}(\mathrm{H} 7 \mathrm{~N} 9)$ virus is naturally adapted to efficient growth in human lung tissue. MBio 4: e00601-13. doi:10.1128/mBio.0060113

Kong H, Zhang Q, Gu C, Shi J, Deng G, Ma S, Liu J, Chen P, Guan Y, Jiang Y, et al. 2015. A live attenuated vaccine prevents replication and transmission of $\mathrm{H7N} 9$ virus in mammals. Sci Rep 5: 11233. doi:10.1038/srep11233

Kong H, Ma S, Wang J, Gu C, Wang Z, Shi J, Deng G, Guan Y, Chen H. 2019. Identification of key amino acids in the $\mathrm{PB} 2$ and $\mathrm{M} 1$ proteins of H7N9 influenza virus that affect its transmission in guinea pigs. J Virol 94: e01180-19.

Lam TTY, Wang J, Shen YY, Zhou BP, Duan L, Cheung CL, Ma C, Lycett SJ, Leung CYH, Chen XC, et al. 2013. The genesis and source of the H7N9 influenza viruses causing human infections in China. Nature 502: 241-244. doi:10 .1038/nature12515

Lam TTY, Zhou BP, Wang J, Chai YJ, Shen YY, Chen XC, Ma C, Hong WS, Chen Y, Zhang YJ, et al. 2015. Dissemination, divergence and establishment of H7N9 influenza viruses in China. Nature 522: 102-105. doi:10.1038/na ture 14348

Lee SS, Wong NS, Leung CC. 2013. Exposure to avian influenza H7N9 in farms and wet markets. Lancet 381: 1815.

Li C, Chen H. 2014. Enhancement of influenza virus transmission by gene reassortment. Curr Top Microbiol 385: 185-204.

Li Z, Chen H, Jiao P, Deng G, Tian G, Li Y, Hoffmann E, Webster RG, Matsuoka Y, Yu K. 2005. Molecular basis of replication of duck H5N1 influenza viruses in a mammalian mouse model. J Virol 79: 12058-12064. doi:10.1128/ JVI.79.18.12058-12064.2005

Li CJ, Bu ZG, Chen HL. 2014a. Avian influenza vaccines against H5N1 'bird flu'. Trends Biotechnol 32: 147-156. doi:10.1016/j.tibtech.2014.01.001 
Li Q, Zhou L, Zhou MH, Chen ZP, Li FR, Wu HY, Xiang NJ Chen EF, Tang FY, Wang DY, et al. 2014b. Epidemiology of human infections with avian influenza A(H7N9) virus in China. New Engl J Med 370: 520-532. doi:10.1056/ NEJMoa1304617

Liang L, Deng GH, Shi JZ, Wang S, Zhang QY, Kong HH, Gu CY, Guan YT, Suzuki Y, Li YB, et al. 2016. Genetics, receptor binding, replication, and mammalian transmission of $\mathrm{H} 4$ avian influenza viruses isolated from live poultry markets in China. J Virol 90: 1455-1469. doi:10.1128/ JVI.02692-15

Liang LB, Jiang L, Li JP, Zhao QQ, Wang JG, He XJ, Huang SY, Wang Q, Zhao YH, Wang GW, et al. 2019. Low polymerase activity attributed to PA drives the acquisition of the PB2 E627K mutation of H7N9 avian influenza virus in mammals. MBio 10: e01162-19.

Linster M, van Boheemen S, de Graaf M, Schrauwen EJA, Lexmond P, Mänz B, Bestebroer TM, Baumann J, van Riel D, Rimmelzwaan GF, et al. 2014. Identification, characterization, and natural selection of mutations driving airborne transmission of A/H5N1 virus. Cell 157: 329-339. doi:10.1016/j.cell.2014.02.040

Liu J, Chen P, Jiang Y, Wu L, Zeng X, Tian G, Ge J, Kawaoka Y, Bu Z, Chen H. 2011. A duck enteritis virus-vectored bivalent live vaccine provides fast and complete protection against $\mathrm{H} 5 \mathrm{~N} 1$ avian influenza virus infection in ducks. J Virol 85: 10989-10998. doi:10.1128/JVI.0542011

Liu Q, Ma J, Strayer DR, Mitchell WM, Carter WA, Ma W, Richt JA. 2014a. Emergence of a novel drug resistant H7N9 influenza virus: evidence based clinical potential of a natural IFN- $\alpha$ for infection control and treatment. Expert Rev Anti-Infect 12: 165-169. doi:10.1586/ 14787210.2014 .870885

Liu QF, Zhou B, Ma WJ, Bawa B, Ma JJ, Wang W, Lang YK, Lyoo Y, Halpin RA, Lin XD, et al. 2014b. Analysis of recombinant H7N9 wild-type and mutant viruses in pigs shows that the Q226L mutation in HA is important for transmission. J Virol 88: 8153-8165. doi:10.1128/JVI .00894-14

Liu W, Fan H, Raghwani J, Lam TT, Li J, Pybus OG, Yao HW, Wo Y, Liu K, An XP, et al. 2014c. Occurrence and reassortment of avian influenza A (H7N9) viruses derived from coinfected birds in China. J Virol 88: 1334413351. doi:10.1128/JVI.01777-14

Liu WL, Bai T, Guo JL, Li XL, Yang L, Wang XJ, Guo JF, Ma X, Li XY, Liu HB, et al. 2016. The S128N mutation combined with an additional potential $N$-linked glycosylation site at residue 133 in hemagglutinin affects the antigenicity of the human H7N9 virus. Emerg Microbes Infec 5: e66.

Liu B, Havers FP, Zhou L, Zhong HJ, Wang XJ, Mao SH, Li H, Ren RQ, Xiang NJ, Shu YL, et al. 2017. Clusters of human infections with avian influenza $A(H 7 N 9)$ virus in China, March 2013 to June 2015. J Infect Dis 216: S548-S554. doi:10.1093/infdis/jix098

Loregian A, Mercorelli B, Nannetti G, Compagnin C, Palù G. 2014. Antiviral strategies against influenza virus: towards new therapeutic approaches. Cell Mol Life Sci 71: 36593683. doi:10.1007/s00018-014-1615-2

Luk GSM, Leung CYH, Sia SF, Choy KT, Zhou J, Ho CCK, Cheung PPH, Lee EF, Wai CKL, Li PCH, et al. 2015 . Transmission of H7N9 influenza viruses with a polymor- phism at PB2 residue 627 in chickens and ferrets. J Virol 89: 9939-9951. doi:10.1128/JVI.01444-15

Ma S, Zhang B, Shi J, Yin X, Wang G, Cui P, Liu L, Deng G, Jiang Y, Li C, et al. 2020. Amino acid mutations A286 V and $\mathrm{T} 437 \mathrm{M}$ in the nucleoprotein attenuate $\mathrm{H} 7 \mathrm{~N} 9$ viruses in mice. J Virol 94: e01530-19.

Mao HY, Guo B, Wang FY, Sun Y, Lou XY, Chen Y, Zhang L, Wang XY, Li Z, Liu SL, et al. 2015. A study of family clustering in two young girls with novel avian influenza A (H7N9) in Dongyang, Zhejiang Province, in 2014. J Clin Virol 65: 90-90. doi:10.1016/j.jcv.2015.01.005

Marjuki H, Mishin VP, Chesnokov AP, De La Cruz JA, Davis CT, Villanuev JM, Fry AM, Gubareva LV. 2015. Neuraminidase mutations conferring resistance to oseltamivir in influenza A(H7N9) viruses. J Virol 89: 5419-5426. doi:10.1128/JVI.03513-14

Matrosovich M, Tuzikov A, Bovin N, Gambaryan A, Klimov A, Castrucci MR, Donatelli I, Kawaoka Y. 2000. Early alterations of the receptor-binding properties of $\mathrm{H} 1, \mathrm{H} 2$, and $\mathrm{H} 3$ avian influenza virus hemagglutinins after their introduction into mammals. J Virol 74: 8502-8512. doi:10.1128/JVI.74.18.8502-8512.2000

Mok CKP, Lee HH, Lestra M, Nicholls JM, Chan MC, Sia SF, Zhu H, Poon LL, Guan Y, Peiris JS. 2014. Amino acid substitutions in polymerase basic protein 2 gene contribute to the pathogenicity of the novel A/H7N9 influenza virus in mammalian hosts. J Virol 88: 3568-3576. doi:10 .1128/JVI.02740-13

Neumann G, Macken CA, Kawaoka Y. 2014. Identification of amino acid changes that may have been critical for the genesis of A(H7N9) influenza viruses. J Virol 88: 48774896. doi:10.1128/JVI.00107-14

Pantin-Jackwood MJ, Miller PJ, Spackman E, Swayne DE, Susta L, Costa-Hurtado M, Suarez DL. 2014. Role of poultry in the spread of novel H7N9 influenza virus in China. J Virol 88: 5381-5390. doi:10.1128/JVI.03689-13

Pielak RM, Schnell JR, Chou JJ. 2009. Mechanism of drug inhibition and drug resistance of influenza A M2 channel. Proc Natl Acad Sci 106: 7379-7384. doi:10.1073/pnas .0902548106

Pinar A, Dowling JK, Bitto NJ, Robertson AA, Latz E, Stewart CR, Drummond GR, Cooper MA, McAuley JL, Tate MD, et al. 2017. PB1-F2 peptide derived from avian influenza A virus $\mathrm{H} 7 \mathrm{~N} 9$ induces inflammation via activation of the NLRP3 inflammasome. J Biol Chem 292: 826-836. doi:10 $.1074 /$ jbc.M116.756379

Pu J, Wang SG, Yin YB, Zhang GZ, Carter RA, Wang JL, Xu GL, Sun HL, Wang M, Wen C, et al. 2015. Evolution of the H9N2 influenza genotype that facilitated the genesis of the novel H7N9 virus. Proc Natl Acad Sci 112: 548-553. doi:10.1073/pnas.1422456112

Pu ZQ, Xiang D, Li XB, Luo TT, Shen XJ, Murphy RW, Liao M, Shen YY. 2018. Potential pandemic of H7N9 avian influenza A virus in human. Front Cell Infect Mi 8: 414. doi:10.3389/fcimb.2018.00414

Qi WB, Shi WF, Li W, Huang LH, Li HA, Wu Y, Yan JH, Jiao PR, Zhu BL, Ma JC, et al. 2014. Continuous reassortments with local chicken H9N2 virus underlie the human-infecting influenza A (H7N9) virus in the new influenza season, Guangdong, China. Protein Cell 5: 878-882. doi:10.1007/s13238-014-0084-6 
Qi WB, Jia WX, Liu D, Li J, Bi YH, Xie SM, Li B, Hu T, Du YY, Xing L, et al. 2018. Emergence and adaptation of a novel highly pathogenic H7N9 influenza virus in birds and humans from a 2013 human-infecting low-pathogenic ancestor. J Virol 92: e00921-17.

Quan CS, Shi WF, Yang Y, Yang YC, Liu XQ, Xu W, Li H, Li J, Wang QL, Tong Z, et al. 2018. New threats from H7N9 influenza virus: spread and evolution of high- and lowpathogenicity variants with high genomic diversity in wave five. J Virol 92: e00301-18.

Ramos I, Krammer F, Hai R, Aguilera D, Bernal-Rubio D, Steel J, García-Sastre A, Fernandez-Sesma A. 2013. H7N9 influenza viruses interact preferentially with $\alpha 2,3$-linked sialic acids and bind weakly to $\alpha 2,6$-linked sialic acids. $J$ Gen Virol 94: 2417-2423. doi:10.1099/vir.0.056184-0

Richard M, Schrauwen EJA, de Graaf M, Bestebroer TM, Spronken MIJ, van Boheemen S, de Meulder D, Lexmond P, Linster M, Herfst S, et al. 2013. Limited airborne transmission of H7N9 influenza A virus between ferrets. $\mathrm{Na}$ ture 501: 560-563. doi:10.1038/nature 12476

Samson M, Pizzorno A, Abed Y, Boivin G. 2013. Influenza virus resistance to neuraminidase inhibitors. Antivir Res 98: 174-185. doi:10.1016/j.antiviral.2013.03.014

Schrauwen EJA, Richard M, Burke DF, Rimmelzwaan GF, Herfst S, Fouchier RAM. 2016. Amino acid substitutions that affect receptor binding and stability of the hemagglutinin of influenza A/H7N9 virus. J Virol 90: 3794-3799. doi:10.1128/JVI.03052-15

Shi JZ, Deng GH, Liu PH, Zhou JP, Guan LZ, Li WH, Li XY, Guo J, Wang GJ, Fan J, et al. 2013a. Isolation and characterization of H7N9 viruses from live poultry marketsimplication of the source of current H7N9 infection in humans. Chin Sci Bull 58: 1857-1863. doi:10.1007/ s11434-013-5873-4

Shi Y, Zhang W, Wang F, Qi JX, Wu Y, Song H, Gao F, Bi YH, Zhang YF, Fan Z, et al. 2013b. Structures and receptor binding of hemagglutinins from human-infecting H7N9 influenza viruses. Science 342: 243-247. doi:10.1126/sci ence. 1242917

Shi JZ, Deng GH, Zeng XY, Kong HH, Wang XY, Lu KP, Wang XR, Mu GD, Xu XL, Cui PF, et al. 2014. Novel influenza $\mathrm{A}(\mathrm{H} 7 \mathrm{~N} 2)$ virus in chickens, Jilin Province, Chi na, 2014. Emerg Infect Dis 20: 1719-1722. doi:10.3201/ eid2010.140869

Shi J, Deng G, Kong H, Gu C, Ma S, Yin X, Zeng X, Cui P, Chen Y, Yang H, et al. 2017. H7N9 virulent mutants detected in chickens in China pose an increased threat to humans. Cell Res 27: 1409-1421. doi:10.1038/cr.2017 .129

Shi J, Deng G, Ma S, Zeng X, Yin X, Li M, Zhang B, Cui P, Chen Y, Yang H, et al. 2018. Rapid evolution of H7N9 highly pathogenic viruses that emerged in China in 2017. Cell Host Microbe 24: 558-568.e7. doi:10.1016/j.chom .2018.08.006

Siegers JY, Short KR, Leijten LME, de Graaf M, Spronken MIJ, Schrauwen EJA, Marshall N, Lowen AC, Gabriel G, Osterhaus ADME, et al. 2014. Novel avian-origin influenza A (H7N9) virus attachment to the respiratory tract of five animal models. J Virol 88: 4595-4599. doi:10.1128/ JVI.03190-13

Sleeman K, Guo Z, Barnes J, Shaw M, Stevens J, Gubareva LV. 2013. R292 K substitution and drug susceptibility of influenza A(H7N9) viruses. Emerg Infect Dis 19: 15211524. doi:10.3201/eid1909.130724

Song WJ, Wang P, Mok BWY, Lau SY, Huang XF, Wu WL, Zheng M, Wen X, Yang SG, Chen Y, et al. 2014. The K526R substitution in viral protein $\mathrm{PB} 2$ enhances the effects of E627 K on influenza virus replication. Nat Commun 5: 5509. doi:10.1038/ncomms6509

Song MS, Marathe BM, Kumar G, Wong SS, Rubrum A, Zanin M, Choi YK, Webster RG, Govorkova EA, Webby RJ. 2015. Unique determinants of neuraminidase inhibitor resistance among N3, N7, and N9 avian influenza viruses. J Virol 89: 10891-10900. doi:10.1128/JVI .01514-15

Steel J, Lowen AC, Mubareka S, Palese P. 2009. Transmission of influenza virus in a mammalian host is increased by PB2 amino acids $627 \mathrm{~K}$ or 627E/701N. PLoS Pathog 5: e1000252. doi:10.1371/journal.ppat.1000252

Stiver G. 2003. The treatment of influenza with antiviral drugs. Can Med Assoc J 168: 49-56.

Su S, Gu M, Liu D, Cui J, Gao GF, Zhou JY, Liu XF. 2017. Epidemiology, evolution, and pathogenesis of H7N9 influenza viruses in five epidemic waves since 2013 in China. Trends Microbiol 25: 713-728. doi:10.1016/j.tim.2017 .06 .008

Subbarao EK, London W, Murphy BR. 1993. A single amino acid in the PB2 gene of influenza A virus is a determinant of host range. J Virol 67: 1761-1764. doi:10.1128/JVI.67.4 $.1761-1764.1993$

Sun X, Belser JA, Pappas C, Pulit-Penaloza JA, Brock N, Zeng $\mathrm{H}$, Creager HM, Le S, Wilson M, Lewis A, et al. 2018. Risk assessment of fifth-wave H7N9 influenza A viruses in mammalian models. J Virol 93: e01740-18.

Sun XJ, Belser JA, Yang H, Pulit-Penaloza JA, Pappas C, Brock N, Zeng H, Creager HM, Stevens J, Maines TR. 2019. Identification of key hemagglutinin residues responsible for cleavage, acid stability, and virulence of fifth-wave highly pathogenic avian influenza A(H7N9) viruses. Virology 535: 232-240. doi:10.1016/j.virol.2019 .07 .012

Tang J, Wang D. 2017. Research progress in human infection with avian influenza H7N9 virus. Sci China Life Sci 60: 1299-1306. doi:10.1007/s11427-017-9221-4

Tharakaraman K, Jayaraman A, Raman R, Viswanathan K, Stebbins NW, Johnson D, Shriver Z, Sasisekharan V, Sasisekharan R. 2013. Glycan receptor binding of the influenza A virus H7N9 hemagglutinin. Cell 153: 1486-1493. doi:10.1016/j.cell.2013.05.034

Tian G, Zhang S, Li Y, Bu Z, Liu P, Zhou J, Li C, Shi J, Yu K, Chen H. 2005. Protective efficacy in chickens, geese and ducks of an H5N1-inactivated vaccine developed by reverse genetics. Virology 341: 153-162. doi:10.1016/j.virol 2005.07.011

Tzarum N, de Vries RP, Peng WJ, Thompson AJ, Bouwman KM, McBride R, Yu WL, Zhu XY, Verheije MH, Paulson JC, et al. 2017. The 150-loop restricts the host specificity of human H10N8 influenza virus. Cell Rep 19: 235-245. doi:10.1016/j.celrep.2017.03.054

van Riel D, Leijten LME, de Graaf M, Siegers JY, Short KR, Spronken MIJ, Schrauwen EJA, Fouchier RAM, Osterhaus A, Kuiken T. 2013. Novel avian-origin influenza A (H7N9) virus attaches to epithelium in both upper and 
C. Li and H. Chen

lower respiratory tract of humans. Am J Pathol 183: 1137 1143. doi:10.1016/j.ajpath.2013.06.011

Vines A, Wells K, Matrosovich M, Castrucci MR, Ito T, Kawaoka Y. 1998. The role of influenza A virus hemagglutinin residues 226 and 228 in receptor specificity and host range restriction. J Virol 72: 7626-7631. doi:10.1128/ JVI.72.9.7626-7631.1998

Wang WJ, Lu B, Zhou HL, Suguitan AL, Cheng X, Subbarao K, Kemble G, Jin H. 2010. Glycosylation at $158 \mathrm{~N}$ of the hemagglutinin protein and receptor binding specificity synergistically affect the antigenicity and immunogenicity of a live attenuated H5N1 A/Vietnam/1203/2004 vaccine virus in ferrets. J Virol 84: 6570-6577. doi:10.1128/JVI $.00221-10$

Wang LP, Cowling BJ, Wu P, Yu JX, Li F, Zeng LJ, Wu JT, Li ZJ, Leung GM, Yu HJ. 2014a. Human exposure to live poultry and psychological and behavioral responses to influenza A(H7N9), China. Emerg Infect Dis 20: 12961305.

Wang Z, Zhang A, Wan Y, Liu X, Qiu C, Xi X, Ren Y, Wang J, Dong Y, Bao M, et al. 2014b. Early hypercytokinemia is associated with interferon-induced transmembrane protein-3 dysfunction and predictive of fatal H7N9 infection. Proc Natl Acad Sci 111: 769-774. doi:10.1073/pnas .1321748111

Wang XY, Chai CL, Li FD, He F, Yu Z, Wang XX, Shang XP, Liu SL, Lin JF. 2015. Epidemiology of human infections with avian influenza $A(\mathrm{H} 7 \mathrm{~N} 9)$ virus in the two waves before and after October 2013 in Zhejiang Province, China. Epidemiol Infect 143: 1839-1845. doi:10.1017/ S095026881400257X

Wang D, Yang L, Zhu W, Zhang Y, Zou S, Bo H, Gao R, Dong J, Huang W, Guo J, et al. 2016. Two outbreak sources of influenza A (H7N9) viruses have been established in China. J Virol 90: 5561-5573. doi:10.1128/JVI.03173-15

Wang NC, Sun MH, Wang WQ, Ouyang GW, Chen ZX, Zhang Y, Zhao BB, Wu SY, Huang JN, Sun HL, et al. 2017. Avian influenza (H7N9) viruses co-circulating among chickens, Southern China. Emerg Infect Dis 23: 2100-2102. doi:10.3201/eid2312.170782

Wang JJ, Su N, Dong ZF, Liu C, Cui PW, Huang JA, Chen C, Zhu YH, Chen LL. 2018. The fifth influenza A(H7N9) epidemic: a family cluster of infection in Suzhou city of China, 2016. Int J Infect Dis 74: 128-135. doi:10.1016/j .ijid.2018.04.4322

Wang XL, Wu P, Pei Y, Tsang TK, Gu DT, Wang W, Zhang JJ, Horby PW, Uyeki TM, Cowling BJ, et al. 2019. Assessment of human-to-human transmissibility of avian influenza $\mathrm{A}(\mathrm{H} 7 \mathrm{~N} 9)$ virus across 5 waves by analyzing clusters of case patients in Mainland China, 2013-2017. Clin Infect Dis 68: 623-631. doi:10.1093/cid/ciy541

Watanabe T, Kiso M, Fukuyama S, Nakajima N, Imai M, Yamada S, Murakami S, Yamayoshi S, Iwatsuki-Horimoto K, Sakoda Y, et al. 2013. Characterization of H7N9 influenza A viruses isolated from humans. Nature 501: 551-555. doi:10.1038/nature12392

Wu J, Ke C, Lau EHY, Song Y, Cheng KL, Zou L, Kang M, Song T, Peiris M, Yen HL. 2019. Influenza H5/H7 virus vaccination in poultry and reduction of zoonotic infections, Guangdong Province, China, 2017-18. Emerg Infect Dis 25: 116-118. doi:10.3201/eid2501.181259
Xiao XC, Li KB, Chen ZQ, Di B, Yang ZC, Yuan J, Luo HB, Ye SL, Liu H, Lu JY, et al. 2014. Transmission of avian influenza $\mathrm{A}(\mathrm{H7N}$ 9) virus from father to child: a report of limited person-to-person transmission, Guangzhou, China, January 2014. Eurosurveillance 19: 14-22.

Xiao C, Ma W, Sun N, Huang L, Li Y, Zeng Z, Wen Y, Zhang Z, Li H, Li Q, et al. 2016. PB2-588 V promotes the mammalian adaptation of H10N8, H7N9 and H9N2 avian influenza viruses. Sci Rep 6: 19474. doi:10.1038/ srep19474

Xie JF, Weng YW, Ou JM, Zhao L, Zhang YH, Wang JZ, Chen W, Huang M, Xiu WQ, Chen HB, et al. 2017. Epidemiological, clinical, and virologic features of two family clusters of avian influenza A (H7N9) virus infections in Southeast China. Sci Rep 7: 1512. doi:10.1038/s41598017-01761-w

Xiong XL, Martin SR, Haire LF, Wharton SA, Daniels RS, Bennett MS, McCauley JW, Collins PJ, Walker PA, Skehel JJ, et al. 2013. Receptor binding by an H7N9 influenza virus from humans. Nature 499: 496-499. doi:10.1038/ nature 12372

Xu JG, Lu S, Wang HY, Chen C. 2013. Reducing exposure to avian influenza H7N9. Lancet 381: 1815-1816.

Xu LL, Bao LL, Deng W, Dong LB, Zhu H, Chen T, Lv Q, Li FD, Yuan J, Xiang ZG, et al. 2014. Novel avian-origin human influenza A(H7N9) can be transmitted between ferrets via respiratory droplets. J Infect Dis 209: 551-556. doi:10.1093/infdis/jit474

Yamayoshi S, Fukuyama S, Yamada S, Zhao D, Murakami S, Uraki R, Watanabe T, Tomita Y, Neumann G, Kawaoka Y. 2015. Amino acids substitutions in the PB2 protein of $\mathrm{H} 7 \mathrm{~N} 9$ influenza A viruses are important for virulence in mammalian hosts. Sci Rep 5: 8039. doi:10.1038/srep08039

Yamayoshi S, Kiso M, Yasuhara A, Ito M, Shu Y, Kawaoka Y. 2018. Enhanced replication of highly pathogenic influenza A(H7N9) virus in humans. Emerg Infect Dis 24: 746750. doi:10.3201/eid2404.171509

Yang ZF, He JF, Li XB, Guan WD, Ke CW, Wu SG, Pan SH, Li RF, Kang M, Wu J, et al. 2014. Epidemiological and viral genome characteristics of the first human H7N9 influenza infection in Guangdong Province, China. $J$ Thorac Dis 6: 1785-1793.

Yang L, Zhu WF, Li XY, Chen MM, Wu J, Yu PB, Qi SX, Huang YW, Shi WX, Dong J, et al. 2017. Genesis and spread of newly emerged highly pathogenic H7N9 avian viruses in Mainland China. J Virol 91: e01277-17.

Yang H, Carney PJ, Chang JC, Guo Z, Stevens J. 2018a. Structural and molecular characterization of the hemagglutinin from the fifth-epidemic-wave A(H7N9) influenza viruses. J Virol 92: e00375-18.

Yang W, Yin X, Guan L, Li M, Ma S, Shi J, Deng G, Suzuki Y, Chen H. 2018b. A live attenuated vaccine prevents replication and transmission of H7N9 highly pathogenic influenza viruses in mammals. Emerg Microbes Infec 7: 153.

Yao YF, Zhang T, Yang WH, Shao ZY, He B, Chen XB, Wu LJ, Jin EG, Liu HZ, Chen JJ, et al. 2018. Avian influenza A (H7N9) virus in a wild land bird in Central China, late 2015. Virol Sin 33: 96-99. doi:10.1007/s12250-0180001-x

Yen HL, McKimm-Breschkin JL, Choy KT, Wong DDY, Cheung PPH, Zhou J, Ng IH, Zhu H, Webby RJ, Guan Y, et al. 2013. Resistance to neuraminidase inhibitors con- 
ferred by an R292 K mutation in a human influenza virus $\mathrm{H} 7 \mathrm{~N} 9$ isolate can be masked by a mixed $\mathrm{R} / \mathrm{K}$ viral population. MBio 4: e00396-13.

Yen HL, Zhou J, Choy KT, Sia SF, Teng OE, Ng IH, Fang VJ, Hu YW, Wang W, Cowling BJ, et al. 2014. The R292K mutation that confers resistance to neuraminidase inhibitors leads to competitive fitness loss of A/Shanghai/1/ 2013 (H7N9) influenza virus in ferrets. J Infect Dis 210 1900-1908. doi:10.1093/infdis/jiu353

Yi LN, Guan DW, Kang M, Wu J, Zeng XQ, Lu J, Rutherford S, Zou LR, Liang LJ, Ni HZ, et al. 2015. Family clusters of avian influenza A H7N9 virus infection in Guangdong Province, China. J Clin Microbiol 53: 22-28. doi:10 .1128/JCM.02322-14

Yu H, Wu JT, Cowling BJ, Liao Q, Fang VJ, Zhou S, Wu P, Zhou H, Lau EH, Guo D, et al. 2014. Effect of closure of live poultry markets on poultry-to-person transmission of avian influenza A H7N9 virus: an ecological study. Lancet 383: 541-548. doi:10.1016/S0140-6736 (13)61904-2

Yu DS, Xiang GF, Zhu WF, Lei X, Li BD, Meng Y, Yang L, Jiao HY, Li XY, Huang WJ, et al. 2019. The re-emergence of highly pathogenic avian influenza H7N9 viruses in humans in mainland China, 2019. Eurosurveillance 24: 13-21.

Yuan J, Lau EH, Li K, Leung YH, Yang Z, Xie C, Liu Y, Liu Y, Ma X, Liu J, et al. 2015. Effect of live poultry market closure on avian influenza $\mathrm{A}(\mathrm{H} 7 \mathrm{~N} 9)$ virus activity in Guangzhou, China, 2014. Emerg Infect Dis 21: 17841793. doi:10.3201/eid2110.150623

Zeng H, Belser JA, Goldsmith CS, Gustin KM, Veguilla V, Katz JM, Tumpey TM. 2015. A(H7N9) virus results in early induction of proinflammatory cytokine responses in both human lung epithelial and endothelial cells and shows increased human adaptation compared with avian H5N1 virus. J Virol 89: 4655-4667. doi:10.1128/JVI .03095-14

Zeng X, Tian G, Shi J, Deng G, Li C, Chen H. 2018. Vaccination of poultry successfully eliminated human infection with H7N9 virus in China. Sci China Life Sci 61: 14651473. doi:10.1007/s11427-018-9420-1

Zhang Q, Shi J, Deng G, Guo J, Zeng X, He X, Kong H, Gu C, Li X, Liu J, et al. 2013a. H7N9 influenza viruses are transmissible in ferrets by respiratory droplet. Science 341: 410-414. doi:10.1126/science.1240532

Zhang Y, Zhang QY, Kong HH, Jiang YP, Gao YW, Deng GH, Shi JZ, Tian GB, Liu LL, Liu JX, et al. 2013b. H5N1 hybrid viruses bearing 2009/H1N1 virus genes transmit in guinea pigs by respiratory droplet. Science 340: 14591463. doi:10.1126/science. 1229455
Zhang H, Li XY, Guo J, Li L, Chang C, Li YY, Bian C, Xu K, Chen HL, Sun B. 2014. The PB2 E627K mutation contributes to the high polymerase activity and enhanced replication of H7N9 influenza virus. J Gen Virol 95: 779-786. doi:10.1099/vir.0.061721-0

Zhang WY, Zhao KF, Jin J, He J, Zhou W, Wu JJ, Tang RS, Ma WB, Ding CY, Liu W, et al. 2019. A hospital cluster combined with a family cluster of avian influenza H7N9 infection in Anhui Province, China. J Infection 79: 49-55. doi:10.1016/j.jinf.2019.05.008

Zhao BH, Zhang X, Zhu WF, Teng Z, Yu XL, Gao Y, Wu D, Pei EL, Yuan ZA, Yang L, et al. 2014. Novel avian influenza $A(H 7 N 9)$ virus in Tree Sparrow, Shanghai, China, 2013. Emerg Infect Dis 20: 850-853. doi:10.3201/eid2005 .131707

Zhao C, Qi X, Ding M, Sun X, Zhou Z, Zhang S, Zen K, Li X. 2016. Pro-inflammatory cytokine dysregulation is associated with novel avian influenza A (H7N9) virus in primary human macrophages. J Gen Virol 97: 299-305. doi:10 $.1099 /$ jgv.0.000357

Zhou J, Wang D, Gao R, Zhao B, Song J, Qi X, Zhang Y, Shi Y, Yang L, Zhu W, et al. 2013. Biological features of novel avian influenza A (H7N9) virus. Nature 499: 500-503. doi:10.1038/nature12379

Zhou L, Tan Y, Kang M, Liu FQ, Ren RQ, Wang YL, Chen T, Yang YP, Li C, Wu J, et al. 2017. Preliminary epidemiology of human infections with highly pathogenic avian influenza A(H7N9) virus, China, 2017. Emerg Infect Dis 23: 1355-1359. doi:10.3201/eid2308.170640

Zhu H, Wang D, Kelvin DJ, Li L, Zheng Z, Yoon SW, Wong SS, Farooqui A, Wang J, Banner D, et al. 2013. Infectivity, transmission, and pathology of human-isolated H7N9 influenza virus in ferrets and pigs. Science 341: 183186. doi:10.1126/science. 1239844

Zhu WF, Li L, Yan ZG, Gan TH, Li LF, Chen RR, Chen RD, Zheng ZY, Hong WS, Wang J, et al. 2015. Dual E627K and D701N mutations in the $\mathrm{PB} 2$ protein of $\mathrm{A}(\mathrm{H} 7 \mathrm{~N} 9)$ influenza virus increased its virulence in mammalian models. Sci Rep 5: 14170. doi:10.1038/srep14170

Zhu H, Lam TT, Smith DK, Guan Y. 2016. Emergence and development of H7N9 influenza viruses in China. Curr Opin Virol 16: 106-113. doi:10.1016/j.coviro.2016 .01 .020

Zhu W, Zhou J, Li Z, Yang L, Li X, Huang W, Zou S, Chen W, Wei H, Tang J, et al. 2017. Biological characterisation of the emerged highly pathogenic avian influenza (HPAI) $\mathrm{A}(\mathrm{H} 7 \mathrm{~N} 9)$ viruses in humans, in mainland China, 2016 to 2017. Eurosurveillance 22: 2-6. 


\section{$\&_{\mathrm{CSH}}^{\infty} \&$ Cold Spring Harbor

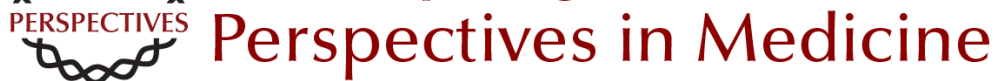

\section{H7N9 Influenza Virus in China}

Chengjun Li and Hualan Chen

Cold Spring Harb Perspect Med 2021; doi: 10.1101/cshperspect.a038349 originally published online March 23, 2020

\section{Subject Collection Influenza: The Cutting Edge}

\section{Emerging HxNy Influenza A Viruses William J. Liu, Yan Wu, Yuhai Bi, et al. \\ Equine Influenza \\ Thomas M. Chambers \\ Human Influenza Epidemiology \\ Sukhyun Ryu and Benjamin J. Cowling}

Host Cell Factors That Interact with Influenza

Virus Ribonucleoproteins

Ecco Staller and Wendy S. Barclay

Induction and Evasion of Type-I Interferon

Responses during Influenza A Virus Infection

Raquel Muñoz-Moreno, Carles Martínez-Romero and Adolfo García-Sastre

Structure and Function of Influenza Polymerase Joanna M. Wandzik, Tomas Kouba and Stephen Cusack

H7N9 Influenza Virus in China Chengjun Li and Hualan Chen

H5 Influenza Viruses in Egypt Rabeh El-Shesheny, Ahmed Kandeil, Ahmed Mostafa, et al.
Antivirals Targeting the Neuraminidase Larisa Gubareva and Teena Mohan

Accessory Gene Products of Influenza A Virus Rute M. Pinto, Samantha Lycett, Eleanor Gaunt, et al.

Influenza Immunization in the Context of

Preexisting Immunity Susanne L. Linderman, Ali H. Ellebedy, Carl Davis, et al.

Hemagglutinin Structure and Activities Steven J. Gamblin, Sébastien G. Vachieri, Xiaoli Xiong, et al.

Live Attenuated Cold-Adapted Influenza Vaccines Kanta Subbarao

Next-Generation Influenza Vaccines Masaru Kanekiyo and Barney S. Graham

\section{Selective Genome Packaging Mechanisms of Influenza A Viruses Takeshi Noda}

Systems Biological Analysis of Immune Response to Influenza Vaccination Mario Cortese, Amy C. Sherman, Nadine G. Rouphael, et al.

For additional articles in this collection, see http://perspectivesinmedicine.cshlp.org/cgi/collection/ 